\title{
GREŠKE U GRAĐENJU I UPOTREBI GLAGOLSKIH VREMENA I NAČINA KOD SRBOFONIH STUDENATA ITALIJANSKOG KAO L2 I ŠPANSKOG KAO L3 USLED NEGATIVNOG TRANSFERA SRODNIH JEZIKA ${ }^{1}$
}

\begin{abstract}
APSTRAKT: Fenomen transfera kod višejezičnih govornika našao se u fokusu istraživanja u oblasti psiholingvistike tokom protekle tri decenije. Empirijska istraživanja sprovedena u ovoj oblasti ukazuju na činjenicu da je negativni transfer najizraženiji kod tipološki sličnih jezika. Ovaj rad analizira greške u građenju i upotrebi glagolskih vremena i načina nastale usled negativnog transfera kod srbofonih studenata koji uče italijanski kao L2 i španski kao L3. Rezultati istraživanja pokazuju da je najveći broj grešaka interlingvalne, a ne intralingvalne prirode, kao i da su greške nastale prevashodno usled međujezičkih identifikacija. Analiza grešaka je takođe pokazala da transfer stvaraju ne samo slični oblici reči već i slična gramatička pravila. Pored navedenog, ispostavilo se i da se broj grešaka smanjuje s porastom nivoa jezičke kompetencije, i L2 i L3.
\end{abstract}

Ključne reči: transfer, glagolska vremena i načini, srpski, italijanski, španski.

\section{ERRORS IN CONSTRUCTION AND USE OF VERB TENSES AND MOODS MADE BY SERBIAN STUDENTS OF ITALIAN AS L2 AND SPANISH AS L3 DUE TO NEGATIVE TRANSFER OF RELATED LANGUAGES}

\begin{abstract}
The phenomenon of transfer in plurilingual speakers has been in the focus of research in the field of psycholinguistics over the past three decades. Empirical research studies conducted in this area indicate that negative transfer is most pronounced in typologically similar languages. This paper analyzes errors in the construction and use of verb tenses and moods caused by negative transfer in Serbophone students learning Italian as L2 and Spanish as L3. The results of the research show that the largest number of errors is of interlingual and not intralingual nature, as well as that the errors occurred primarily due to interlingual identifications. The error analysis proved that transfer is created not only by similar word forms but also by similar grammatical rules. Also, it has been proven that the number of errors decreases with increasing levels of language competence in both L2 and L3.
\end{abstract}

Key words: transfer, verb tenses and moods, Serbian, Italian, Spanish.

\footnotetext{
${ }^{1}$ Istraživanje je sprovedeno za potrebe doktorske disertacije odbranjene 2019. godine na Filološkom fakultetu u Beogradu.
} 


\section{TEORIJSKI OKVIR ISTRAŽIVANJA}

Fenomen transfera (međujezičkog uticaja) kod višejezičnih govornika našao se $u$ fokusu istraživanja $u$ oblasti psiholingvistike tokom protekle tri decenije. Premda su teoretičari kontrastivne analize tvrdili da će sličnosti između polaznog i ciljnog jezika olakšati učenje, a razlike izazvati poteškoće u učenju, empirijska istraživanja sprovedena u ovoj oblasti u poslednjih tridesetak godina ukazuju na činjenicu da je negativni transfer najizraženiji upravo kod tipološki srodnih jezika (Williams \& Hammarberg 1998; De Angelis \& Selinker 2001; Cenoz 2001; Ecke 2001; Hammarberg 2001; Ringbom 2001). Zahvaljujući prevashodno faktorima jezičke tipologije i psihotipologije, dokazano je da upravo međujezičke sličnosti prouzrokuju najveći broj grešaka i favorizuju pojavu negativnog transfera prilikom učenja novog jezika (Swan 1997).

\subsection{Definicija i vrste transfera}

Pod pojmom jezičkog transfera podrazumeva se upotreba znanja maternjeg ili nekog drugog jezika tokom učenja drugog ili dodatnog jezika (Gass \& Selinker 1983: 372). Transfer se može dogoditi na različitim jezičkim nivoima, u različitim pravcima, u produkciji ili razumevanju. Uticaj prethodnog znanja na učenje novog jezika može biti pozitivan ili negativan. Pozitivnim transferom smatra se onaj koji doprinosi olakšavanju učenja ili upotrebe ciljnog jezika. Prema ishodu koji može imati na učenje postoji i negativni transfer. On nastaje onda kada preneseno znanje iz $\mathrm{L}^{2}$ ili ranije naučenog stranog jezika dovede do stvaranja negramatičkih ili komunikativno neprikladnih rečenica u jeziku koji se trenutno uči. Zbog toga je ovu vrstu transfera lako identifikovati.

Jedna od prvih grana kontrastivne lingvistike koja se bavila fenomenom transfera bila je kontrastivna analiza. Njena osnovna pretpostavka bila je da će sličnosti olakšati učenje, a razlike izazvati poteškoće u učenju L2. Teoretičari kontrastivne analize tvrdili su da su, što su jezici udaljeniji i razlika veća između

\footnotetext{
2 Skraćenicama L1 označava se prvi, L2 drugi, a L3 treći jezik. Pri ovome se ne misli isključivo na hronološki redosled učenja jezika (budući da su informanti ranije učili i neke druge strane jezike, npr. engleski), već na trenutni stepen kompetencije govornika u svakom od njih (Groseva 1998), gde je L1- maternji i najdominantniji jezik govornika (srpski), L2 - strani jezik u kome imaju najviši nivo kompetencije (italijanski) i L3 - jezik u kom su najmanje fluentni (španski).
} 
dva sistema, veće i poteškoće, a da su poteškoće manje kada su jezici bliži i sličniji (Weinreich 1953: 1).

Empirijska istraživanja (Williams \& Hammarberg 1998; De Angelis \& Selinker 2001; Hammarberg 2001; Ringbom 2001) dokazala su suprotno: ukoliko su u kontaktu jezici iz iste jezičke porodice, u pojedinim fazama učenja negativni transfer će se češće javljati nego kod jezika koji nisu srodni. Ovo je bila početna pretpostavka u našem istraživanju.

Pored efekta koji ima na učenje ciljnog jezika, transfer se može klasifikovati i prema pravcu delovanja. Džarvis i Pavlenko (Jarvis \& Pavlenko 2008: 73) daju sledeću podelu transfera: transfer prema napred (forward transfer) L1 utiče na nematernji ciljni jezik koji se kasnije uči, transfer prema nazad (reverse transfer) - transfer ide iz nematernjeg jezika na L1 i bočni transfer (lateral transfer) - u umu višejezičnih govornika nematernji jezik utiče na drugi nematernji ciljni jezik, npr. L2 $\rightarrow$ L3.

Prema oblasti znanja ili upotrebe jezika transfer može biti: pravopisni, fonetski, leksički, semantički, morfološki, sintaksički, diskursivni, pragmatički, sociolingvistički (Jarvis \& Pavlenko 2008: 20). Morfološki transfer podrazumeva uticaj strukture reči jednog jezika na produkciju ili razumevanje strukture reči na drugom jeziku, dok se sintaksički odnosi ne samo na transfer redosleda reči, već $i$ na uticaj čitave jezičke strukture na produkciju ili razumevanje drugog jezika. U našem istraživanju bavili smo se negativnim, bočnim, morfološko-sintaksičkim transferom.

\subsection{Jezička tipologija i psihotipologija}

Postoje brojni faktori koji mogu usloviti pojavu transfera, a među najvažnije spadaju jezička tipologija i psihotipologija.

Jezička tipologija govori o stvarnoj strukturnoj bliskosti između jezika, onoj koju je moguće objektivno izmeriti (De Angelis 2007: 22). Za mnoge lingviste (Williams \& Hammarberg 1998; Dewaele 1998) proučavanje zajedničkih karakteristika (fonetskih, fonoloških, leksičkih, morfoloških, sintaksičkih, diskursnih) i određivanje stepena tipoloških sličnosti koje postoje među jezicima smatra se ključnim u određivanju obima međujezičkog uticaja u učenju i korišćenju ciljnog jezika. Do kraja 80-tih godina XX veka, pod snažnim uticajem biheviorističkog učenja i kontrastivne analize, a imajući u vidu slučajeve bilingvala, verovalo se da objektivne strukturne sličnosti između jezika mogu olakšati proces učenja ciljnog jezika. Danas, zahvaljujući istraživanjima u oblasti učenja trećeg jezika (Williams \& Hammarberg 1998; Dewaele 1998; De Angelis \& 
Selinker 2001; Ringbom 2001), sa sigurnošću se tvrdi da će se kod tipološki srodnih jezika, u pojedinim fazama učenja, negativni transfer češće javljati nego kod jezika koji nisu slični.

Psihotipologija je učenikova subjektivna procena stepena tipološke bliskosti između jezika. Udaljenost između jezika može se posmatrati kao lingvistički fenomen, utvrđivanjem stvarne jezičke razlike između dva jezika, ili kao psiholingvistička pojava, određivanjem onoga što učenici jezika misle da je stepen razlike između polaznog i ciljnog jezika (Ellis 1994: 327). Psihotipologija označava način na koji učenik doživljava jezičku udaljenost između maternjeg jezika i jezika koji uči, odnosno stepen podudaranja za koji govornik veruje da postoji između ta dva jezika. Upravo to subjektivno opažanje bliskosti jezika pokazalo se kao važnije za pojavu transfera od stvarne, tipološki potvrđene bliskosti, jer su brojna istraživanja transfera (De Angelis \& Selinker 2001; Jarvis \& Pavlenko 2008) dokazala da se interferencija češće pojavljuje između onih jezika i jezičkih struktura koje učenik smatra najbližim. Drugim rečima, učenik pravi pretpostavke o jeziku koji uči. Učenikova percepcija jezičke distance će određivati prenosivost elemenata između jezika. Ukoliko učenik veruje da su polazni i ciljni jezik u nekom smislu isti, doći će do transfera. Istovremeno, transfer će biti zaustavljen ukoliko izostane učenikov subjektivni sud o međujezičkoj bliskosti.

Ovaj koncept prenesen je i na kontekst trojezičnosti i višejezičnosti. Ako se u jezičkom repertoaru učenika nađu L1 koji učenik ne doživljava povezanim sa ciljnim jezikom i L2 koji učenik percipira kao povezan sa ciljnim jezikom, učenik će se više oslanjati na znanje L2 nego na svoj maternji jezik. Dakle, verovatnije je da će doći do transfera, i pozitivnog i negativnog, ukoliko učenik, u skladu sa svojim subjektivnim shvatanjem, doživi jezike kao bliske ili povezane na bilo koji način.

\section{UČESNICI I KORPUS}

Istraživanje se zasniva na podacima dobijenim iz pisane produkcije četrdeset srbofonih studenata italijanskog jezika Filološkog fakulteta Univerziteta $u$ Beogradu i Filološko-umetničkog fakulteta u Kragujevcu, tokom četiri akademske godine (2015-2019). Učesnici, starosti između 20-25 godina, studirali su kao prvi jezik italijanski, a kao drugi španski jezik. Informanti su počeli da pohađaju kurs španskog kao L3 od početnog nivoa (A1.1), dok je nivo znanja italijanskog jezika kao L2 bio B2 (samoprocena). Analiza grešaka korpusa sprovedena je posle završene prve, a potom i posle završene druge godine kursa španskog jezika. 
Korpus je sačinjen iz tri dela. Prvi deo predstavljaju eseji na španskom koje su studenti pisali na zadate teme - opisivanje osobe, porodice, putovanja, opisivanje kuće, škole, praznika, kupovine, mode i društvenih mreža. Drugi deo sastoji se od pismenih sastava na temu opisa zadate slike, a treći čini prevod rečenica sa srpskog na španski jezik. Prevod rečenica nije spadao u kurikulum fakulteta, već predstavlja posebno osmišljen autorski materijal napravljen s ciljem da se uvide najučestaliji slučajevi negativnog transfera. Metoda kojom je obrađen korpus jeste analiza grešaka.

\section{ANALIZA KORPUSA}

Detaljnom analizom grešaka pronađenih u korpusu dolazi se do zaključka da se greške vezane za kategoriju glagola tiču sledećih načina: indikativa (prezent, futur I i prošla vremena), konjunktiva, kondicionala i imperativa.

\subsection{Indikativ}

\subsubsection{Prezent}

U italijanskom i španskom jeziku prezent indikativa se gradi dodavanjem ličnih nastavaka na osnovu dobijenu odbacivanjem nastavka za infinitiv. Takođe, oba vremena razlikuju tri konjugacije i, osim pravilnih, poseduju veliki broj nepravilnih glagola.

Nastavci za građenje sadašnjeg vremena pravilnih glagola u italijanskom i španskom dati su u Tabeli 1:

\begin{tabular}{|c|c|c|c|c|c|c|}
\hline \multicolumn{7}{|c|}{ Prezent u italijanskom jeziku } \\
\hline \multicolumn{3}{|c|}{ parlare } & \multicolumn{2}{|c|}{ credere } & \multicolumn{2}{|c|}{ partire } \\
\hline \multicolumn{2}{|c|}{ jednina } & \multirow{2}{*}{$\begin{array}{c}\text { množina } \\
\text { parl-iamo }\end{array}$} & \multirow{2}{*}{$\begin{array}{c}\text { jednina } \\
\text { cred-o }\end{array}$} & \multirow{2}{*}{$\begin{array}{c}\text { množina } \\
\text { cred-iamo }\end{array}$} & \multirow{2}{*}{$\begin{array}{c}\text { jednina } \\
\text { part-o }\end{array}$} & \multirow{2}{*}{$\frac{\text { množina }}{\text { part-iamo }}$} \\
\hline 1.lice & parl-o & & & & & \\
\hline 2.lice & parl-i & parl-ate & cred-i & cred-ete & part-i & part-ite \\
\hline 3.lice & parl-a & parl-ano & cred-e & cred-ono & part-e & part-ono \\
\hline \multicolumn{7}{|c|}{ Prezent u španskom jeziku } \\
\hline \multicolumn{3}{|c|}{ hablar } & \multicolumn{2}{|c|}{ creer } & \multicolumn{2}{|c|}{ partir } \\
\hline \multicolumn{2}{|c|}{ jednina } & množina & jednina & množina & jednina & množina \\
\hline 1.lice & habl-o & habl-amos & cre-o & cre-emos & part-o & part-imos \\
\hline 2.lice & habl-as & habl-áis & cre-es & cre-éis & part-es & part-ís \\
\hline 3.lice & habl-a & habl-an & cre-e & cre-en & part-e & part-en \\
\hline
\end{tabular}

Tabela 1. Prezent u italijanskom jeziku i Prezent u španskom jeziku 
Nastavci za prvo i treće lice jednine su identični, nastavak za treće lice množine glagola prve konjugacije je sličan, dok su ostali nastavci različiti u dva jezika.

Upravo je sličnost prikazana u nastavku za treće lice množine izazvala negativni transfer iz jednog jezika u drugi, i to prevashodno kod glagola koji su u oba jezika slični u obliku infinitiva ili značenju: ayudano* umesto ayudan prema italijanskom aiutano; comprano $* \square$ umesto compran prema italijanskom comprano; cuestano* umesto cuestan prema italijanskom costano; hablano* umesto hablan prema italijanskom parlano; pagano* umesto pagan prema italijanskom pagano; practicano* umesto practican prema italijanskom praticano; saludano* umesto saludan prema italijanskom salutano; se lavano* umesto se lavan prema italijanskom si lavano; viajano* umesto viajan prema italijanskom viaggiano.

Naredna vrsta greške pronađena u korpusu ticala se dodavanja italijanskih nastavaka za građenje prezenta na osnovu španskih glagola. I u ovom slučaju je u pitanju bila sličnost glagola u oba jezika, tako da navedeni slučajevi (osim primera hibridne tvorevine organizi) predstavljaju potpune pozajmljenice. Hibridne tvorevine su reči koje su pretrpele morfološke ili fonetske modifikacije u skladu sa pravilima ciljnog jezika. Potpune pozajmljenice predstavljaju one reči u L3 koje su u potpunosti preuzete iz ranije naučenog jezika - L2, a koje nisu doživele nikakvu modifikaciju u skladu sa pravilima L3 (De Angelis 2007: 42). Slede primeri grešaka: dai* umesto das prema italijanskom dai; eviti* umesto evitas prema italijanskom eviti; organizi * umesto organizas prema italijanskom organizzi; vieni * umesto vienes prema italijanskom vieni; vivi* umesto vives prema italijanskom vivi.

Kada je u pitanju korišćenje prezenta nije bilo grešaka, s obzirom na to da se upotreba ovog vremena u oba jezika podudara, što je primer za pozitivni transfer u procesu učenja srodnih jezika.

\subsubsection{Futur I}

Kako se veliki broj grešaka vezanih za buduće vreme tiče oblika glagola, daćemo kratak pregled građenja ovog vremena u oba jezika.

Futur I u italijanskom i španskom jeziku gradi se na način prikazan u Tabeli 2. 


\begin{tabular}{|c|c|c|c|c|c|}
\hline \multicolumn{6}{|c|}{ Futur I u italijanskom jeziku } \\
\hline \multicolumn{2}{|c|}{ parlare } & \multicolumn{2}{|c|}{ credere } & \multicolumn{2}{|c|}{ partire } \\
\hline jednina & množina & jednina & množina & jednina & množina \\
\hline 1.lice parl-erò & parl-eremo & cred-erò & cred-eremo & part-irò & part-iremo \\
\hline 2.lice parl-erai & parl-erete & cred-erai & cred-erete & part-irai & part-irete \\
\hline parl-erà & parl-eranno & cred-erà & cred-eranno & part-irà & part-iranno \\
\hline \multicolumn{6}{|c|}{ Futur I u španskom jeziku } \\
\hline \multicolumn{2}{|c|}{ hablar } & \multicolumn{2}{|c|}{ creer } & \multicolumn{2}{|c|}{ partir } \\
\hline jednina & množina & jednina & množina & jednina & množina \\
\hline 1.lice hablar-é & hablar-emos & creer-é & creer-emos & partir-é & partir-emos \\
\hline hablar-ás & hablar-éis & creer-ás & creer-éis & partir-ás & partir-éis \\
\hline hablar-á & hablar-án & creer-á & creer-án & partir-á & partir-án \\
\hline
\end{tabular}

Tabela 2. Futur I u italijanskom jeziku i Futur I u španskom jeziku

Dakle, futur I pravilnih glagola u italijanskom jeziku gradi se dodavanjem identičnih nastavaka: -rò, -rai, -rà, -remo, -rete, -ranno, pri čemu druga i treća konjugacija zadržavaju svoj tematski vokal, a prva svoj tematski vokal menja iz $a \mathrm{u}$ $e$. Građenje futura I pravilnih glagola u španskom jeziku je jednostavnije. Na infinitiv se dodaju sledeći nastavci: -é, -ás, -á, -emos, -éis, -án.

Jedna od dve greške koje se tiču građenja vremena predstavljala je korišćenje italijanskih nastavaka za građenje futura I uz španske glagole: ayudaró* umesto ayudaré prema italijanskom aiuterò; compraró* umesto compraré prema italijanskom comprerò; estudiaró * umesto estudiaré prema italijanskom studierò; llevaró * umesto llevaré prema italijanskom porterò; pasaró* umesto pasaré prema italijanskom passerò; trabajeró* umesto trabajeré prema italijanskom lavorerò; hablaremo* umesto hablaremos prema italijanskom parleremo.

Druga greška koja je u vezi sa oblikom glagola u futuru I bila je primena italijanskog pravila o promeni tematskog vokala $a$ u $e$ u prvoj konjugaciji na španske glagole: paseré* umesto pasaré; compreré* umesto compraré; envieré* umesto enviaré; espereré* umesto esperaré; me relajeré* umesto me relajaré; intenteré* umesto intentaré; tomeré* umesto tomaré; pregunteré* umesto preguntaré; manderé* umesto mandaré; paserás* umesto pasarás; ayuderá* umesto ayudará; estudierá* umesto estudiará; comenzerá* umesto comenzará; empezerá* umesto empezará; trabajerá* umesto trabajará; terminerá* umesto terminará; regreserá * umesto regresará; se quederá * umesto se quedará; gusterá* umesto gustará; descanserá* umesto descansará; paserá* umesto pasará; llegerá* 
umesto llegará; feliciterá* umesto felicitará; paseremos* umesto pasaremos; costerán* umesto costarán ${ }^{3}$.

U korpusu je identifikovana i greška vezana za upotrebu futura I. U italijanskom jeziku upotreba futura I dozvoljena je u protazi realnih kondicionalnih rečenica (Se avrò tempo, leggerò il libro - Ako budem imao vremena pročitaću knjigu). U španskom jeziku u ovakvoj vrsti kondicionalnih rečenica upotreba futura I nije dozvoljena, već je u tom slučaju neophodno koristiti prezent (Si tengo tiempo, leeré el libro). Ovo je bila najučestalija greška koju je napravilo 87,5\% studenata prve i $67,5 \%$ studenata druge godine:

- si vendrás (umesto si vienes) verás que te vas a sentir mejor;

- si irá al médico (umesto si va al médico) probablemente el médico le ayudará;

- si querrás (umesto si quieres) tener más tiempo libre, deberás organizarte mejor.

Srpski, maternji jezik informanata, takođe nije mogao da bude izvor transfera, budući da bi se $u$ tom jeziku, u pogodbenim rečenicama ovog tipa, $u$ protazi pojavio futur II.

\subsubsection{Prošla vremena}

\subsubsection{Passato prossimo i Pretérito perfecto}

Pravilna upotreba prošlih vremena $u$ romanskim jezicima generalno predstavlja poteškoću srbofonim govornicima zbog činjenice da se u srpskom, njihovom maternjem jeziku, upotreba prošlih vremena svela na korišćenje perfekta. U radu se nećemo baviti najčešćim problemima sa kojima se govornici srpskog jezika susreću u trenutku kada treba da odaberu i upotrebe tačno prošlo vreme u italijanskom i španskom, već onima koji su nastali kao proizvod negativnog transfera iz L2 u L3.

Prvo vreme kod kojeg je primećen veći broj grešaka jeste italijanski Passato prossimo, koji se gradi na isti način kao španski Pretérito perfecto, tj. od pomoćnog glagola u prezentu i participa prošlog glavnog glagola. Ipak, postoji nekoliko razlika. Prva od njih odnosi se na sam pomoćni glagol. U italijanskom jeziku, u zavisnosti od toga da li je glavni glagol prelazan ili neprelazan (ako

\footnotetext{
${ }^{3}$ Razloge za ovakvu pojavu treba tražiti u istorijskoj gramatici italijanskog jezika. Za više informacija konsultovati Patota (2002: 68-69).
} 
zanemarimo izuzetke i specifične slučajeve), koriste se dva pomoćna glagola: avere i essere. U španskom jeziku postoji samo jedan pomoćni glagol - haber, koji se upotrebljava za građenje složenih vremena svih glagola. Pored toga, u italijanskom, particip glavnog glagola slaže se u rodu i broju sa subjektom ukoliko je pomoćni glagol essere.

$\mathrm{U}$ Tabeli 3. prikazana je promena italijanskih glagola parlare i venire, $\mathrm{i}$ španskih hablar i venir, kako bi se konjugacije mogle uporediti i razumeti uzrok pojave transfera.

\begin{tabular}{|c|c|c|c|c|}
\hline \multicolumn{5}{|c|}{ Passato prossimo } \\
\hline \multicolumn{3}{|c|}{ parlare } & \multicolumn{2}{|c|}{ venire } \\
\hline jednina & & množina & jednina & množina \\
\hline 1.lice & ho parlato & abbiamo parlato & sono venuto/a & siamo venuti/e \\
\hline 2.lice & hai parlato & avete parlato & sei venuto/a & siete venuti/e \\
\hline 3.lice & ha parlato & hanno parlato & è venuto/a & sono venuti/e \\
\hline \multicolumn{5}{|c|}{ Pretérito perfecto } \\
\hline \multicolumn{3}{|c|}{ hablar } & \multicolumn{2}{|c|}{ venir } \\
\hline jednina & & množina & jednina & množina \\
\hline 1.lice & he hablado & hemos hablado & he venido & hemos venido \\
\hline 2.lice & $\begin{array}{c}\text { has } \\
\text { hablado }\end{array}$ & habéis hablado & has venido & habéis venido \\
\hline 3.lice & ha hablado & han hablado & ha venido & han venido \\
\hline
\end{tabular}

Tabela 3. Passato prossimo i Pretérito perfecto

Kada je u pitanju građenje vremena Pretérito Perfecto u španskom, naišli smo na nekoliko vrsta grešaka u korpusu:

1. upotreba oblika pomoćnog glagola avere umesto oblika glagola haber: ho visto* umesto he visto; ho cambiado* umesto he cambiado; ho encontrado* umesto he encontrado; ho hablado* umesto he hablado; ho dicho* umesto he dicho; ho trabajado* umesto he trabajado; ho comprado* umesto he comprado; ho visitado* umesto he visitado; hai conocido* umesto has conocido; hai pensado* umesto has pensado.

2. upotreba glagola ser kao pomoćnog (iako se španski glagoli ser ili estar ne koriste za građenje složenih vremena) u onim slučajevima kada bi se glagol essere koristio kao pomoćni u italijanskom jeziku, tj. uz neprelazne i povratne glagole: soy estada* umesto he estado; soy venida* umesto he venido; soy llegada* umesto he llegado; soy regresada* umesto he regresado; es venido* umesto ha venido; ella es llegada* umesto ella ha 
llegado; es diventada* umesto se ha hecho; es muerta* umesto ha muerto; son pasados tres años* umesto han pasado tres años; me soy lavada* umesto me he lavado; me soy vestida* umesto me he vestido; me soy acostada* umesto me he acostado; se es movido* umesto se ha movido.

3. upotreba participa koji se završavaju na -ato i -ito umesto ispravnih španskih oblika koji se završavaju na -ado i -ido, čineći ove oblike ili hibridnim tvorevinama ili potpunim pozajmljenicama. $\mathrm{Na}$ primer: encontrato* umesto encontrado; mostrato* umesto mostrado; saludato* umesto saludado; movito* umesto movido; soñato* umesto soñado; enamorato * umesto enamorado; amato * umesto amado; pasato* umesto pasado; vestito* umesto vestido; aceptato* umesto aceptado; recibito* umesto recibido.

4. slaganje participa $\mathrm{u}$ rodu i broju sa subjektom - pravilo koje postoji u italijanskom, ali ne i u španskom jeziku: soy estada* umesto he estado; soy venida* umesto he venido; soy llegada* umesto he llegado; soy ida* umesto he ido; ella es llegada* umesto ella ha llegado; ella es venida* umesto ella ha venido; es muerta* umesto ha muerto; son pasados* umesto han pasado; me soy lavada* umesto me he lavado; me soy vestida* umesto me he vestido; me soy acostada* umesto me he acostado; se es convertida* umesto se ha convertido.

Uprkos tome što se italijansko prošlo vreme Passato prossimo gradi na isti način kao prošlo vreme Pretérito perfecto u španskom jeziku, upotreba ova dva vremena se ne podudara, jer je navedenom italijanskom vremenu po upotrebi sličniji španski Pretérito indefinido. Passato prossimo se koristi da označi radnje koje su se dogodile u nedavnoj prošlosti čije se psihološke ili emotivne posledice osećaju u sadašnjosti, ali i radnje koje su se odigrale u dalekoj prošlosti koje ni na koji način nisu povezane sa sadašnjim trenutkom (Moderc 2004: 305). Pretérito perfecto nužno upućuje na radnje koje su povezane sa sadašnjim trenutkom i koje su se dogodile u prošlosti neposredno pre trenutka govora, radnje koje su se desile u trenutku koji nije vremenski određen i radnje čije se posledice osećaju u sadašnjosti (Rajić \& Marcos Blanco 2009: 76). Stoga će se koristiti uz priloške odredbe za vreme poput: hoy, esta mañana, esta semana, este año, nunca, siempre, ya, hasta ahora, desde ayer, por el momento. Sa druge strane, Pretérito indefinido koji po oblicima više podseća na italijanski Passato remoto, upućuje na radnju koju govornik smatra završenom u prošlosti i koja nema nikakve veze sa sadašnjim 
trenutkom, te se koristi uz: ayer, la semana pasada, el mes pasado, el año pasado, anoche, entonces, en 1999, hace dos meses, hace dos años, hace dos días (Rajić \& Marcos Blanco 2009: 74), a koristi se u govornom jeziku podjednako često kao Pretérito perfecto.

Uprkos tome, a usled pogrešno izvedene analogije zbog sličnosti u građenju vremena Passato prossimo i Pretérito perfecto, studenti (85\% na prvoj i $72,5 \%$ na drugoj godini) koriste vreme Pretérito perfecto umesto vremena Pretérito indefinido u slučajevima kada bi u italijanskom upotrebili Passato prossimo:

- me he ido a Italia en 2011 * umesto me fui a Italia en 2011;

- lo he visto hace dos días * umesto lo vi hace dos días;

- se ha mudado a esa ciudad hace algunos años* umesto se mudó a esa ciudad hace algunos años;

- he trabajado con él hace 20 años * umesto trabajé con él hace 20 años;

- ayer he encontrado las flores delante de la puerta* umesto ayer encontré las flores delante de la puerta;

- mi coche se ha roto ayer* umesto mi coche se rompió ayer;

- he recibido tu mensaje el miércoles pasado* umesto recibí tu mensaje el miércoles pasado;

- lo he conocido el año pasado en el mar* umesto lo conocí el año pasado en el mar;

- el verano pasado he estado de camarero en un bar* umesto el verano pasado estuve de camarero en un bar;

- la semana pasada he visto una película * umesto la semana pasada vi una película

- He nacido en 1998* umesto Nací en 1998.

\subsubsection{Italijanski imperfetto $i \check{s}$ panski imperfecto}

Budući da su se u slučaju imperfekta problemi javljali više kod oblika nego $\mathrm{u}$ upotrebi vremena, u Tabeli 4 . ćemo prikazati kako se ovo vreme gradi u italijanskom i španskom jeziku. 


\begin{tabular}{|c|c|c|c|c|c|c|}
\hline \multicolumn{7}{|c|}{ Imperfekat u italijanskom jeziku } \\
\hline \multicolumn{3}{|c|}{ parlare } & \multicolumn{2}{|c|}{ credere } & \multicolumn{2}{|c|}{ partire } \\
\hline \multicolumn{2}{|c|}{ jednina } & množina & jednina & množina & \multirow{2}{*}{$\frac{\text { jednina }}{\text { part-ivo }}$} & \multirow{2}{*}{$\frac{\text { množina }}{\text { part-ivamo }}$} \\
\hline 1.lice & $\begin{array}{c}\text { parl- } \\
\text { avo }\end{array}$ & parl-avamo & cred-evo & cred-evamo & & \\
\hline 2.lice & parl-avi & parl-avate & cred-evi & cred-evate & part-ivi & part-ivate \\
\hline 3.lice & $\begin{array}{c}\text { parl- } \\
\text { ava }\end{array}$ & parl-avano & cred-eva & cred-evano & part-iva & part-ivano \\
\hline \multicolumn{7}{|c|}{ Imperfekat u španskom jeziku } \\
\hline \multicolumn{3}{|c|}{ hablar } & \multicolumn{2}{|c|}{ creer } & \multicolumn{2}{|c|}{ partir } \\
\hline & dnina & množina & jednina & množina & jednina & množina \\
\hline 1.lice & habl-aba & $\begin{array}{c}\text { habl- } \\
\text { ábamos }\end{array}$ & cre-ía & cre-íamos & part-ía & part-íamos \\
\hline 2.lice & habl-abas & habl-abais & cre-ías & cre-íais & part-ías & part-íais \\
\hline 3.lice & habl-aba & habl-aban & cre-ía & cre-1́an & part-ía & part-ían \\
\hline
\end{tabular}

Tabela 4. Imperfekat u italijanskom jeziku i Imperfekat u španskom jeziku

Poređenjem dve tabele i imajući u vidu da su sve do sada analizirane greške usled negativnog transfera nastale prevashodno kod sličnih reči, ne iznenađuje što među najučestalije greške na koje smo naišli u korpusu spadaju:

1. korišćenje italijanskog nastavka -o za građenje prvog lica jednine imperfekta, umesto španskog nastavka - $a$ : hablabo* umesto hablaba; tomabo* umesto tomaba; pensabo* umesto pensaba; soñabo* umesto soñaba; estabo * umesto estaba; (yo) ero* umesto (yo) era;

2. korišćenje italijanskog nastavka -vo i -va umesto španskog nastavka za građenje imperfekta glagola prve konjugacije -ba: hablavo* umesto hablaba; pensavo* umesto pensaba; me gustava* umesto me gustaba; jugava* umesto jugaba; tomava* umesto tomaba; pensava* umesto pensaba; hablava* umesto hablaba; se tratava* umesto se trataba; cambiava* umesto cambiaba; soñava* umesto soñaba; contava* umesto contaba; mirava* umesto miraba;

3. korišćenje nastavka za građenje imperfekta glagola prve konjugacije prilikom građenja imperfekta glagola druge $i$ treće konjugacije. U italijanskom jeziku imperfekat ima jedinstvene nastavke za sve tri konjugacije (-vo, -vi, -va, -vamo, -vate, -vano) pri čemu svaka konjugacija zadržava svoj tematski vokal, dok u španskom jeziku postoje oblici: - $a b a$, abas, -aba, -ábamos, -abais, -aban za prvu, i: -ía, -ías, -ía, -íamos, -íais, ían za drugu i treću konjugaciju. Zbog evidentnog negativnog transfera iz 
italijanskog studenti su koristili nastavke tipične za prvu konjugaciju prilikom građenja imperfekta glagola sve tri konjugacije: comeba* ili comeva* umesto comía; bebeba*, bebeva* ili bebiba* umesto bebía; teneba* umesto tenia; vendeba* umesto vendía; veniba* umesto venía; diceba* umesto decía; saliba* umesto salía; se sentiba* ili se sentiva* umesto se sentía; comebamos* umesto comíamos.

\subsection{Italijanski konjunktiv $i$ španski subjunktiv}

Italijanski konjunktiv (congiuntivo) i španski subjunktiv (subjuntivo) su načini koji ne postoje u srpskom jeziku. Kao takve, srbofoni govornici ih izjednačavaju u ova dva romanska jezika, odnoso doživljavaju ih kao sličnije nego što to zaista jesu. Konjunktiv i subjunktiv jesu načini kojima se izražava neizvesnost ili nesigurnost ostvarenja radnje. Njima se izražava subjektivnost, a radnja se predstavlja kao moguća, verovatna ili proizvod ličnog mišljenja. Uprkos tome, upotreba italijanskog konjunktiva i španskog subjunktiva ne podudara se $\mathrm{u}$ svim slučajevima. Na primer, u italijanskom jeziku konjunktiv se koristi u zavisnim rečenicama posle glagola koji izražavaju lično mišljenje ili stav (Penso che Lorenzo sia ricco), dok se španski subjunktiv upotrebljava samo uz negaciju glagola koji izražavaju mišljenje (No creo que me comprenda bien). Dalje, u španskom se subjunktiv upotrebljava posle vremenskog veznika: cuando, apenas za izražavanje dve simultane radnje u budućnosti (Podrás jugar cuando termines tu tarea), što u italijanskom jeziku nije slučaj. Navedena razlika u upotrebi italijanskog konjunktiva i španskog subjunktiva će biti uzrok najvećeg broja studentskih grešaka.

Grešku izazvanu transferom iz italijanskog u španski predstavlja upotreba subjunktiva posle glagola koji izražavaju mišljenje. Ovakvi glagoli, ukoliko ispred njih nije upotrebljena negacija, $\mathrm{u}$ španskom jeziku zahtevaju indikativ:

- pienso que sea imposible * umesto pienso que es imposible;

- pienso que los dos vestidos sean largos* umesto pienso que los dos vestidos son largos;

- creo que no sea facil vivir aquí* umesto creo que no es facil vivir aquí;

- creo que haya ido al parque* umesto creo que ha ido al parque;

- me parece que sea* umesto me parece que es.

Učestala greška (87,5\% studenata druge godine) bila je i korišćenje infinitiva umesto subjunktiva u slučajevima kada je to dozvoljeno u italijanskom, 
ali ne i u španskom jeziku. U italijanskom se konjunktiv koristi posle glagola koji izražavaju naredbu (Proibisco che tu fumi qui). Uprkos gramatičkom pravilu, $\mathrm{u}$ praksi se retko sreću primeri upotrebe konjunktiva posle glagola naredbe. Naime, ukoliko je u rečenici prisutan logički subjekat u obliku indirektnog objekta, u italijanskom se radije koristi implicitna konstrukcija s predlogom $d i$ i infinitivom: Ti proibisco di fumare qui. Španski subjunktiv upotrebljava se posle glagola koji izražavaju naredbu ili savet (Prohíbo que fumes aquí). Slično kao u italijanskom jeziku, u španskom se umesto subjunktiva može koristiti infinitiv ako je u rečenici prisutan subjekat koji se odnosi na infinitiv (Rajić \& Marcos Blanco 2009: 157; Romero Dueñas \& González Hermoso 2015: 240): Te prohíbo que fumes aquí ili Te prohíbo fumar aquí. Posle glagola koji izražavaju naredbu ili savet, čak i u slučajevima kada je izražen subjekat $u$ obliku indirektnog objekta (dativa) na koji se infinitiv odnosi, u španskom nije dozvoljena upotreba infinitiva ukoliko je eksplicitno naveden još jedan subjekat. Drugim rečima može se reći: Te pido enviar la carta, ali nije gramatički ispravno reći: Te pido ayudarme*, već je u drugom slučaju neophodno upotrebiti subjunktiv: Te pido que me ayudes. $\mathrm{U}$ italijanskom jeziku dozvoljena je upotreba infinitiva u oba slučaja: Ti chiedo di spedire la lettera i Ti chiedo di aiutarmi. Upravo je ova pogrešna analogija doprinela stvaranju negativnog transfera iz L2 u L3, odnosno građenju implicitne rečenice u slučaju kada to nije gramatički prihvatljivo u španskom jeziku:

- te digo de dejarme en paz* umesto te digo que me dejes en paz prema italijanskom ti dico di lasciarmi in pace;

- te pido (de) ayudarme* umesto te pido que me ayudes prema italijanskom ti chiedo di aiutarmi;

- te ruego (de) hacerme un favor* umesto te ruego que me hagas un favor prema italijanskom ti supplico di farmi un favore;

- te ruego (de) ayudarme* umesto te ruego que me ayudes prema italijanskom ti supplico di aiutarmi.

Izuzetno visok procenat studenata (97,5\% na drugoj godini) upotrebio je prezent, futur I ili futur II umesto subjunktiva posle veznika cuando i apenas u zavisnoj vremenskoj rečenici, što predstavlja očigledan direktan transfer iz italijanskog jezika:

- cuando vuelvo a casa* umesto cuando vuelva a casa prema italijanskom

- quando torno a casa;

- cuando mi primo viene te voy a escribir* umesto cuando mi primo venga te voy 
- a escribir prema italijanskom quando mio cugino viene ti scrivo;

- cuando la obra terminará* umesto cuando la obra termine prema italijanskom quando lo spettacolo finirà;

- cuando acabará sus estudios* umesto cuando acabe sus estudios prema italijanskom quando finirà i suoi studi;

- cuando habrá terminado la Universidad* umesto cuando termine la Universidad prema italijanskom quando avrà finito l'Università;

- cuando lo habré hecho, saldré* umesto cuando lo haga, saldré prema italijanskom quando lo avrò fatto, uscirò.

Dok je pogrešna upotreba futura II ili prezenta mogla da bude uslovljena transferom iz srpskog jezika, upotreba futura I u navedenim konstrukcijama jasno pokazuje da je transfer potekao iz italijanskog.

U korpusu postoji još jedna česta greška u upotrebi španskog subjunktiva. U italijanskoj rečenici, posle glagola koji zahtevaju konjunktiv, moguće je upotrebiti futur I za izražavanje buduće radnje. Takva opcija ne postoji u španskom jeziku, već je upotreba subjunktiva obavezna:

Penso che Paolo viene ili verrà. Mislim da će Paolo doći.

Penso che Paolo venga. Mislim da Paolo dolazi.

Penso che Paolo sia venuto. Mislim da je Paolo došao.

No pienso que Pablo vendrá *

No pienso que Pablo venga. Ne mislim da Pablo dolazi ili da će doći.

No pienso que Pablo haya venido. Ne mislim da je Pablo došao.

Sledeći primeri iz korpusa ilustruju pogrešnu upotrebu futura I umesto subjunktiva:

- tengo miedo que se quedará en casa* umesto tengo miedo de que se quede en casa prema italijanskom ho paura che rimarrà a casa;

- espero que le gustará* umesto espero que le guste prema italijanskom spero che le piacerà;

- no creo que llegará* umesto no creo que llegue prema italijanskom non credo che arriverà.

Poređenjem navedenih primera uočava se da, i pored brojnih sličnosti, postoje razlike $u$ upotrebi ovog načina $u$ italijanskom i španskom jeziku. Greške uslovljene negativnim transferom proizvod su uverenja studenata da se sva pravila vezana za italijanski konjunktiv mogu primeniti i na španski subjunktiv. 


\subsection{Kondicional}

Prilikom korišćenja kondicionala studenti su pravili dve vrste grešaka. Prva se ticala oblika kondicionala, a druga njegove upotrebe.

Kondicional I se u španskom jeziku, kao i u italijanskom, gradi prema pravilima po kojima se gradi futur I. Shodno tome, prilikom pravljenja španskih kondicionala I studenti su pravili iste greške koje su pravili pri građenju futura I. Najfrekventnija greška odnosila se na menjanje tematskog vokala kod glagola prve konjugacije: gustería* umesto gustaría; lleverías* umesto llevarías; pasería* umesto pasaría; comprería * umesto compraría; te ayudería * umesto te ayudaría; estudiería * umesto estudiaría.

Kada je u pitanju upotreba kondicionala u španskom jeziku najčešća greška (97,5\% studenata druge godiine) odnosila se na upotrebu ovog načina prema pravilima o slaganju vremena. Kondicional I (kondicional sadašnji) se u španskom jeziku koristi u indirektnom govoru da izrazi buduće radnje iz perspektive prošlosti:

Dijo que compraría una casa. Rekao je da će kupiti kuću.

$\mathrm{U}$ italijanskom se umesto kondicionala sadašnjeg $\mathrm{u}$ istoj situaciji koristi kondicional II (prošli):

Disse che avrebbe comprato una casa. Rekao je da će kupiti kuću.

Studenti su u španskom jeziku koristili kondicional prošli umesto kondicionala sadašnjeg za izražavanje buduće radnje iz perspektive prošlosti:

- lo que prometío que habría hecho* umesto lo que prometío que haría prema italijanskom quello che ha promesso che avrebbe fatto;

- prometió que habría venido para Pascua* umesto prometió que vendría para Pascua prema italijanskom ha promesso che sarrebe venuto per Pasqua;

- pensaba que habríamos ido al mar* umesto pensaba que iríamos al mar prema italijanskom pensavo che saremmo andati al mare.

\subsection{Imperativ}

Greške vezane za imperativ javile su se u oblicima glagola, a ne u njegovoj upotrebi. Studenti su koristili italijanske nastavke za građenje imperativa umesto španskih. Poređenjem oblika prikazanih u Tabeli 5, može se objasniti pojava transfera. 
GREŠKE U GRAĐENJU I UPOTREBI GLAGOLSKIH VREMENA I NAČINA KOD ...

\begin{tabular}{|c|c|c|c|c|c|c|}
\hline \multicolumn{7}{|c|}{ Imperativ u italijanskom jeziku } \\
\hline \multicolumn{3}{|c|}{ parlare } & \multicolumn{2}{|c|}{ credere } & \multicolumn{2}{|c|}{ partire } \\
\hline & ina & množina & jednina & množina & jednina & množina \\
\hline 1.lice & & parl-iamo & & cred-iamo & & part-iamo \\
\hline 2.lice & parl-a & parl-ate & cred-i & cred-ete & part-i & part-ite \\
\hline 3.lice & parl-i & parl-ino & cred-a & cred-ano & part-a & part-ano \\
\hline \multicolumn{7}{|c|}{ Imperativ u španskom jeziku } \\
\hline \multicolumn{3}{|c|}{ hablar } & \multicolumn{2}{|c|}{ creer } & \multicolumn{2}{|c|}{ partir } \\
\hline \multicolumn{2}{|c|}{ jednina } & množina & jednina & množina & jednina & množina \\
\hline 1.lice & & habl-emos & & cre-amos & & part-amos \\
\hline 2.lice & habl-a & habl-ad & cre-e & cre-ed & part-e & part-id \\
\hline 3.lice & habl-e & habl-en & cre-a & cre-an & part-a & part-an \\
\hline
\end{tabular}

Tabela 5. Imperativ u italijanskom jeziku i Imperativ u španskom jeziku

Primeri iz korpusa pokazuju da su studenti koristili italijanske nastavke za građenje imperativa umesto adekvatnih španskih nastavaka: jescribime!* umesto ¡escríbeme!; jimagini! * umesto jimagine!; ;dejate! * umesto jdejad!

U italijanskom jeziku nastavak za imperativ drugog lica množine identičan je nastavku za prezent. U španskom nastavak za imperativ drugog lica množine ima karakterističan nastavak koji se uvek završava na $-d$. I pored toga studenti su gradili drugo lice imperativa na način na koji se to radi $u$ italijanskom, $t j$. dodavanjem nastavka za sadašnje vreme indikativa: ¡dejais!* umesto ;dejad!; ¡olvidais! * umesto ;olvidad!

Sledeća grupa grešaka odnosila se na građenje negativnog imperativa drugog lica jednine. U italijanskom jeziku on se gradi od non + infinitiv, dok se u španskom jeziku gradi od no + subjunktiv prezenta: No lo tirar!* umesto ¡No lo tires!; ¡No tirarlo! * umesto ¡No lo tires!; ¡No lo olvidar! * umesto ¡No lo olvides!; ¡No olvidarlo! * umesto ¡no lo olvides!; ¡No echarla! * umesto ¡no la eches!

Poslednja vrsta grešaka ticala se građenja imperativa trećeg lica jednine i položaja zamenica. U italijanskom jeziku sve vrste zamenica se nalaze ispred oblika imperativa trećeg lica jednine kao proklitike. U španskom, ukoliko se radi o pozitivnom imperativu, zamenice se spajaju sa trećim licem jednine imperativa, dakle enklitike su, dok se nalaze ispred negativnog imperativa trećeg lica jednine: ¡Usted me de las llaves! * umesto ¡Usted deme las llaves! prema italijanskom mi dia le chiavi!; ¡me las de! * umesto ¡démelas! prema italijanskom me le dia!

$\mathrm{U}$ radu su pobrojane greške koje su informanti pravili tokom dve godine pohađanja kursa španskog jezika, pri čemu su i dalje intenzivno učili italijanski jezik. Analizirana je pisana produkcija studenata posle prve, a zatim i posle druge godine učenja španskog jezika. Dobijeni podaci ukazuju na činjenicu da su greške 
ostale iste, što govori o važnosti uticaja faktora tipologije i psihotipologije, ali se procenat studenata koji su pravili greške smanjio sa porastom znanja L3, ali i L2. Navedeno ukazuje da je u procesu učenja tipološki sličnih jezika važan i faktor označen kao „nivo znanja jezika”.

$\mathrm{Na}$ Grafikonu 1. prikazan je procenat studenata koji je pravio morfosintaksičke greške u produkciji na španskom tokom dve godine učenja ovog jezika. Obradom korpusa saznajemo da je greške vezane za prezent indikativa napravilo 42,5\% studenata tokom prve godine učenja španskog jezika, dok je njihov broj posle druge godine učenja L3 bio znatno manji - 22,5\%. Kada je u pitanju buduće vreme, izuzetno visok procenat studenata $(87,5 \%)$ pravio je greške tokom prve godine kursa španskog. Procenat studenata koji je pogrešno gradio i upotrebljavao futur I posle druge godine učenja španskog bio je i dalje dosta visok (67,5\%), ali znatno niži nego tokom prve godine učenja. Kada je reč o prošlim vremenima, $85 \%$ studenata prve i $72,5 \%$ studenata druge godine grešilo je u građenju i upotrebi vremena Passato prossimo, dok je nešto niži procenat $(62,5 \%$ posle prve i $42,5 \%$ posle druge godine) imao problem sa imperfektom.

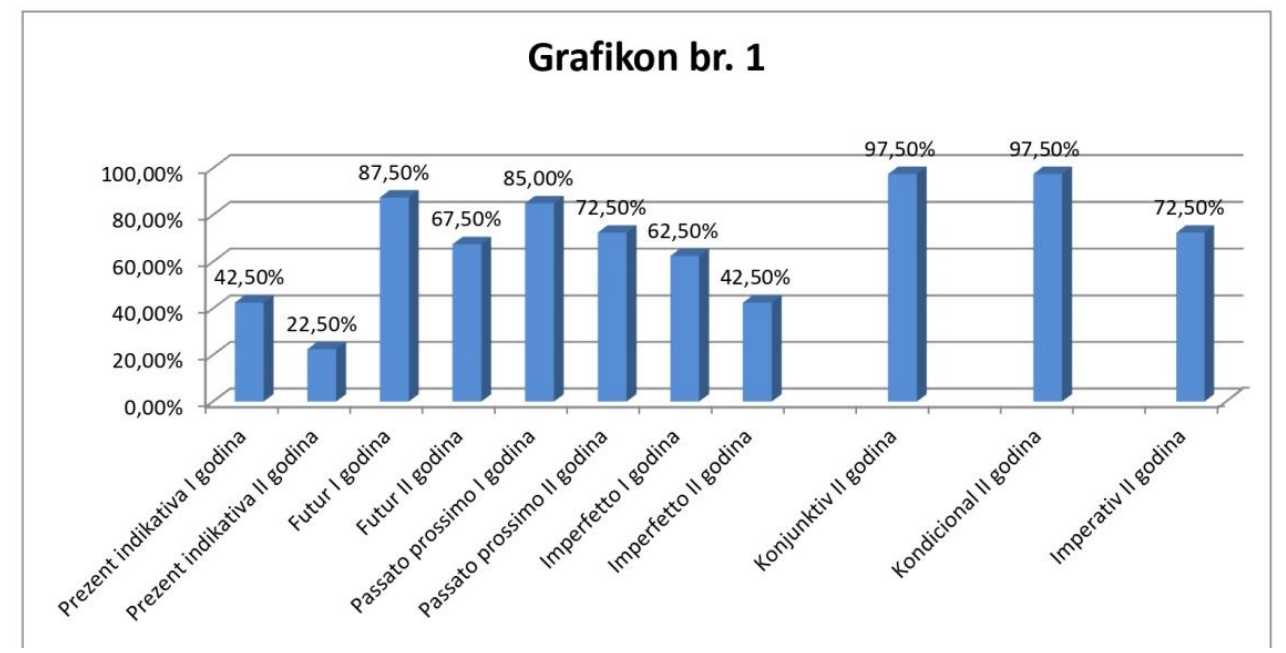

Grafikon 1. Procenat studenata koji je pravio morfosintaksičke greške

Kako kurikulum predviđa učenje kondicionala, konjunktiva i imperativa na drugoj godini kursa španskog jezika, nije bilo moguće ispitati faktor nivoa znanja jezika, ali je evidentno da je visok procenat studenata pravio greške kod navedenih kategorija. Grafikon pokazuje da se broj grešaka nastalih zbog negativnog transfera redukovao s porastom znanja i L2 i L3, odnosno sa porastom lingvističkog iskustva studenata, ali da je negativan transfer prilikom učenja 
tipološki sličnih jezika prisutan, usled uticaja faktora jezičke tipologije i psihotipologije.

\section{ZAKLJUČAK}

U radu smo se bavili analizom međujezika u pisanoj produkciji srbofonih studenata koji uče srodne romanske jezike, s ciljem da otkrijemo, analiziramo i klasifikujemo najučestalije interlingvalne morfosintaksičke greške nastale usled negativnog transfera iz nematernjeg, ranije naučenog, italijanskog jezika na nematernju produkciju španskog kao L3. Identifikovane greške pokazuju da je negativni transfer jači kod tipološki srodnih jezika nego kod onih koji to nisu, bez obzira na redosled učenja, budući da maternji jezik govornika nije bio uzrok negativnog transfera. Na pojavu transfera presudan uticaj imala je jezička tipologija. Budući da je najveći broj grešaka uočen kod onih oblika ili pravila koji su u italijanskom i španskom jeziku slični, dokazano je da tipološka bliskost između L2 i L3 olakšava jezički transfer. Pokazano je da nematernji jezici mogu biti izvor transfera, te kod proučavanja ovog fenomena ne treba obratiti pažnju samo na uticaj maternjeg jezika na ciljni jezik, već prevashodno na uticaj L2 na ciljni jezik, posebno u slučaju kada je L2 tipološki najbliži L3. Ovome bismo dodali da interferencija ne zavisi samo od stvarne, objektivne sličnosti između L1 i L2, već i od drugih faktora poput, na primer, psihotipologije. Između italijanskog i španskog jezika postoji objektivna tipološka sličnost, ali ih srbofoni govornici doživljavaju još sličnijim nego što to zaista jesu. Navedeno je u skladu sa rezultatima pojedinih istraživanja (Jarvis \& Pavlenko 2008) koja su dokazala da se interferencija češce javlja između onih jezika i jezičkih struktura koje student smatra najbližim. Dakle, i psihotipologija doprinosi nastanku tranfera, i to negativnog. Usled uticaja faktora jezičke tipologije i psihotipologije, dokazano je da međujezičke sličnosti prouzrokuju najveći broj grešaka i favorizuju pojavu negativnog bočnog transfera.

Analiza morfosintaksičkih grešaka pokazala je da transfer stvaraju ne samo slični oblici već i slična gramatička pravila. Na primer, italijanski konjunktiv sličan je španskom subjunktivu, ali se upotreba ovog načina ne poklapa u svim slučajevima, što je bio osnovni uzrok pojave negativnog transfera. Slučajevi transfera usled sličnih oblika evidentni su prevashodno kod futura I, dok je najviše grešaka koje se tiču lažnih analogija kod gramatičkih pravila počinjeno pri upotrebi sledećih vremena: futur I, perfekat, imperfekat i načina: konjunktiv, kondicional i imperativ. 
Greške u korpusu nisu nastale isključivo zbog nepoznavanja pravila španskog jezika, već su nastale zbog uticaja koji je na učenje L3 imalo znanje prethodno naučenog italijanskog jezika. Najveći broj grešaka bio je interlingvalne prirode, budući da mnoge od grešaka identifikovanih u korpusu (npr. promena tematskog vokala kod glagola prve konjugacije u futuru I) ne bi napravili učenici koji su prethodno učili neki drugi jezik, tipološki udaljen od španskog.

Najzad, u procesu učenja tipološki sličnih jezika važnost ima i nivo znanja i ciljnog i prethodno naučenih jezika. Istraživanje je pokazalo da se broj grešaka smanjuje kako raste nivo L3, ali i L2.

\section{LITERATURA}

Cenoz, J. (2001). The effect of linguistic distance, L2 status, and age on crosslinguistic influence in third language acquisition, in Cross-linguistic Influence in Third Language Acquisition: Psycholinguistic Perspectives, eds. J. Cenoz, B. Hufeisen \& U. Jessner (Clevedon: Multilingual Matters): 8-20.

De Angelis, G., Selinker, L. (2001). Interlanguage transfer and competing linguistic systems in the multilingual mind, in Cross-Linguistic Influence in Third Language Acquisition: Psycholinguistic Perspectives, eds. J. Cenoz, B. Hufeisen \& U. Jessner (Clevedon: Multilingual Matters): 42-58.

De Angelis, G. (2007). Third or Additional Language Acquisition. Clevedon: Multilingual Matters.

Dewaele, J. M. (1998). Lexical Inventions: French Interlanguage as L2 versus L3. Applied Linguistics 19: 471-490.

Ecke, P. (2001). Lexical retrieval in a third language: evidence from errors and tipof- the-tongue states, in Cross-linguistic Influence in Third Language Acquisition: Psycholinguistic Perspectives, eds. J. Cenoz, B. Hufeisen \& U. Jessner (Clevedon: Multilingual Matters): 90-114.

Ellis, R. (1994). The study of second language acquisition. Oxford: OUP.

Gass, S., Selinker, L. (1983). Language transfer in language learning. Rowley, MA: Newbury House.

Groseva, M. (1998). Dient das L2-System als ein Fremdsprachenlernmodell?, in Tertiärsprachen: Theorien, Modell, Methoden, eds. B. Hufeisen \& B. Lindermann (Tübingen: Stauffenburg): 21-30.

Hammarberg, B. (2001). Roles of L1 and L2 in L3 production and acquisition, in Cross-Linguistic Influence in Third Language Acquisition: 
Psycholinguistic Perspectives, eds. J. Cenoz, B. Hufeisen \& U. Jessner (Clevedon: Multilingual Matters): 21-41.

Jarvis, S., Pavlenko, A. (2008). Crosslinguistic influence in language and cognition. New York: Routledge.

Moderc, S. (2004). Gramatika italijanskog jezika. Beograd: Udruženje nastavnika italijanskog jezika Srbije.

Patota, G. (2002). Lineamenti di grammatica storica dell'italiano. Bologna: il Mulino.

Rajić, J., Marcos Blanco, H. (2009). Gramática de la lengua española para serbiohablantes. Beograd: Zavod za udžbenike.

Ringbom, H. (2001). Lexical transfer in L3 production, in Cross-linguistic Influence in Third Language Acquisition: Psycholinguistic Perspectives, eds. J. Cenoz, B. Hufeisen \& U. Jessner (Clevedon: Multilingual Matters): $59-68$.

Romero Dueñas, C., González Hermoso, A. (2015). Gramática del español lengua extranjera. Madrid: Edelsa.

Swan, M. (1997). The influence of the mother tongue on second language vocabulary Acquisition and use. Pristupljeno 19. 4. 2017. URL: <https://mikeswan.net/wp-content/uploads/2017/08/The-influence-\%E2 $\% 80 \%$ A6.pdf>.

Weinreich, U. (1953). Languages in Contact. New York: Linguistic Circle of New York.

Williams, S., Hammarberg, B. (1998). Language switches in L3 production: Implications for a polyglot speaking model. Applied Linguistics 19 (3): 295-333.

Marija Vujović

Logos - Language school

ERRORS IN CONSTRUCTION AND USE OF VERB TENSES AND MOODS MADE BY SERBIAN STUDENTS OF ITALIAN AS L2 AND SPANISH AS L3 DUE TO NEGATIVE TRANSFER OF RELATED LANGUAGES

\section{Summary}

The phenomenon of transfer in plurilingual speakers has been in the focus of research in the field of psycholinguistics over the past three decades. Empirical research studies conducted in this area indicate that negative transfer is most pronounced in typologically similar languages. Thanks to the factors of language distance and 
psychotypology, it has been proven that interlingual similarities are the ones that cause the largest number of errors and favor the occurrence of negative lateral transfer. This paper analyzes errors in the construction and use of verb tenses and moods caused by negative transfer in Serbophone students learning Italian as L2 and Spanish as L3. The results of the research show that the largest number of errors is of interlingual and not intralingual nature, as well as that the errors occurred primarily due to interlingual identifications. In other words, the most frequent errors in students' written production concern the similarities that exist between Italian and Spanish, while the mother tongue of the participants has never been a source of negative transfer in this corpus. The analysis proved that transfer is created not only by similar word forms but also by similar grammatical rules. Also, it has been proven that the number of errors decreases with increasing levels of language competence in both L2 and L3.

Key words: transfer, verb tenses and moods, Serbian, Italian, Spanish.

Primljeno: 21. 1. 2021.

Prihvaćeno: 26. 7. 2021. 